\title{
Medical manslaughter: the role of hindsight
}

\author{
Gilberto KK Leung *, FHKAM (Surgery), LLM \\ Department of Surgery, LKS Faculty of Medicine, The University of Hong Kong, Hong Kong \\ *Corresponding author: gilberto@hku.hk
}

Hong Kong Med J 2021;27:240-1

https://doi.org/10.12809/hkmj215117

A 46-year-old woman died after receiving a bacteriacontaminated blood product at a beauty clinic in Hong Kong in 2012. The clinic owner, the technician concerned, and the doctor who administered the transfusion were convicted of gross negligence manslaughter in the now-infamous "DR case".,2 Whilst few, if any, would condone the conduct of the individuals responsible, the principles underpinning the criminal conviction of the third defendant warrant our attention.

Gross negligence manslaughter is a form of involuntary manslaughter where the degree of negligence is so "reprehensible", so "truly exceptionally bad" that it amounts to a crime. A key element of the offence is that it must have been reasonably foreseeable that the breach of duty of care in question carried a "serious and obvious risk of death" and had indeed caused death. The applicable legal test is an objective one. ${ }^{2}$

As its name implies, the objective test does not look into the accused's own state of mind but asks whether a reasonably competent doctor in the accused's position would have foreseen a "serious and obvious risk of death". An affirmative answer would point to liability subject to the other requirements being met.

The way the objective test operates depends on the kind of information the hypothetical "reasonable doctor" possesses. Should the hypothetical doctor in the context of fatal medical treatment consider only information known to the accused at the time of giving the treatment, ie, looking at the situation prospectively? Or should the hypothetical doctor benefit from hindsight and also take into consideration information that eventually transpired, ie, a retrospective exercise? A fine point of technicality, perhaps, but a pivotal one at that.

In the English case of Rose, an optometrist failed to examine a young boy's fundi adequately and missed his papilloedema. ${ }^{3} \mathrm{He}$ later died of hydrocephalus, and the optometrist was convicted of gross negligence manslaughter. Her conviction was quashed on appeal on the ground that although she should have examined the child properly and discovered papilloedema, since she did not, she could not have reasonably foreseen a serious and obvious risk of death, and neither would a hypothetical optometrist in the same state of "ignorance". And this, the Court of Appeal found, would not suffice for the conviction.

A similar argument also overturned the conviction of a restaurant chef from Lancashire, United Kingdom, who served a fatal takeaway meal containing peanuts to a customer who had declared peanuts allergy. ${ }^{4}$ Although the chef should have known about the allergy, he did not know because of a communication breakdown within the restaurant, and the conviction could not stand.

A curious effect of the above line of reasoning is that the less one does and the less one knows, the less culpable one seems to become in the eyes of the criminal law. One may also argue that a reasonably competent optometrist/chef would not have made those mistakes in the first place. But the court in Rose was not saying the optometrist was not wrong; she was just not criminally wrong, and the appropriate sanctions should come from professional regulatory bodies instead. Indeed, the optometrist was found unfit to practise by the General Optical Council and suspended for 9 months.

The objective test is thus a prospective one according to these recent cases which, when applied in a blood transfusion case, would not take into account things that would have been known to the doctor but for the failure to check for contamination, nor the fact that the patient later died of septicaemia. Instead, it would ask whether a hypothetical reasonable doctor, not knowing or suspecting that the blood product was contaminated, would have reasonably foreseen a serious and obvious risk of death at the moment of giving it. If answered in the negative, there can be no manslaughter conviction.

How the objective test was applied in the "DR case" cannot be gleaned from the published judgement, and this author is not second-guessing the wisdom of the court as the case has its unique facts and considerations. What can be said is that the objective test, if applied in a retrospective manner, would have engaged a degree of hindsight few of us would enjoy when being the one in the dock, and that the very reason why the original conviction in Rose was found unsafe was that the trial judge had erred in directing the jury to apply the objective test retrospectively.

Some would no doubt, and quite rightly, say that basic human conscience and professional duties require doctors to always check for safety and a failure to do so ought to invite at least some 
kind of punishment had the failure resulted in patient death. Two issues follow. First, how much checking is enough? That a system is in place to check for contamination? A technician had signed off the treatment? The technician's credentials? That he actually did his job? Second, should a failure to do all or indeed any one of the above be treated as a potential crime? How often do we check that everything we are given to give is bacteria-free? Should there be a distinction between oversight and conscious violation of established safety rules? Is failing to check manslaughter?

Rose is of course not binding in Hong Kong, and being a Court of Appeal decision it has not changed the law although it does offer a nuanced application of the objective test. What we, as healthcare professionals, need to stay mindful and critical of, though, is how the offence of and the legal test for gross negligence manslaughter are to be invoked, articulated, and applied in this locality. Criminal liability is founded on the concepts of reasonable foreseeability and moral blameworthiness, and whilst hindsight is invaluable for learning, it is a lousy tool for determining whether and when a human error in medicine should be met with the consequence of years behind bars. It may not be up to us to decide what the law is or how it works, but we can surely decide that the debate be continued, here and elsewhere. ${ }^{5}$

\section{Author contributions}

The author is solely responsible for drafting of the manuscript, approved the final version for publication, and takes responsibility for its accuracy and integrity.

\section{Conflicts of interest}

The author has disclosed no conflicts of interest.

\section{References}

1. HKSAR v Chow Heung Wing Stephen \& Ors [2018] HKCFI 60

2. HKSAR v Mak Wan Ling [2020] HKCFI 3069

3. Mullock A. Gross negligence (medical) manslaughter and the puzzling implications of negligent ignorance: Rose $\mathrm{v}$ R [2017] EWCA Crim 1168. Med Law Rev 2018;26:34656.

4. $R v$ Kuddus [2019] EWCA Crim 837

5. Leung GK. Medical manslaughter in Hong Kong-how, why, and why not. Hong Kong Med J 2018;24:384-90. 